\title{
ICU 退室後の予期せぬ院内死亡に関する危険因子の検討
}

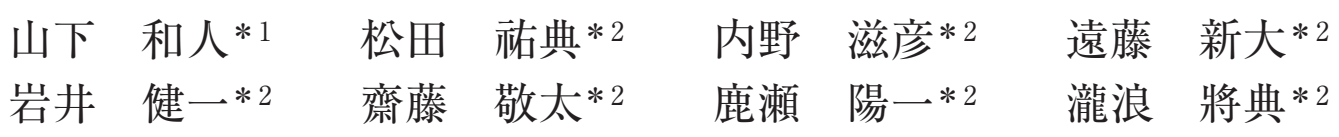

\begin{abstract}
要約：【目的】ICU患者には, ICU 退室後も予期せ㛡内死亡の危険性が存在する。そこで, 当施設のICU 退室後患者を調查し, 院内死亡の危険因子を検討した。【方法】後方視的診療録 調查。2006～2008年にICUに入室した患者のうち，48時間以内に退室，18歳未満，ICU再入 室症例, ICU内で死亡, 治療を差し控えてのICU 退室を除いた 570 症例を対象とした。【結果】 56 症例が院内で死亡していた。独立した院内死亡の危険因子 [odds ratio (95\% confidence interval) ]は, 病棟からのICU入室 $[2.69(1.22 \sim 5.96)]$, 癌転移 $[41.0(4.70 \sim 357)]$, 血液悪 性疾患 [9.71 (2.26 41.7) ], Acute Physiology and Chronic Health Evaluation (APACHE) II スコアの上昇 $[1.11(1.06 \sim 1.16)$ per point $]$, 再挿管の施行 $[5.59(1.87 \sim 16.6)]$, 人工呼吸器を 装着してのICU 退室 [3.19（1.31～7.80) 〕であった。【結論】 ICU 退室患者の約1割が院内で死亡 していた。
\end{abstract}

Key words: (1) mortality, (2) post ICU discharge

\section{序 論}

本来, ICUは回復可能な重症病態にある患者に対し て集中治療を行う部門であり, 筆者らの施設において もそのような患者に対して集中治療を提供している。 しかし, 実際にはICU 退室後に院内で死亡する患者が 少なからず存在する 11 。海外においては ICU 退室後院 内死亡の危険因子について, 複数の研究が行われてい るが，国内においては検討が十分になされていない。 そこで今回, ICU退室後の院内死亡に関する検討を後 方視的に行い，死亡に関わる危険因子を検討した。

\section{対象と方法}

東京慈恵会医科大学附属病院は都内にある約 1,080 床の大学病院で, 12 床のICUを有し, 5 ～名の専従 医が所属する semi-closedタイプのICUである。明文 化された入退室基準はなく, 患者の重症度, 改善度を 考慮して, ICU専従医と主治療科医師との合議で入退 室を決定している。また, 満床時の夜間緊急入室が発
生した際には, ICU在室患者の中で最軽症例を夜間退 室の対象としている。本検討では, 当ICUに 2006 年 1 月 1 日から 2008 年 12 月 31 日までに入室したのべ 3,672 症例のうち, (1) 48 時間以内に退室 (2,413症例),

(2)18歳未満 (441症例), (3)ICU再入室 (196症例, 同 一患者を複数回カウントしてしまうことを避けるた め, 初回入室のみを検討対象とした), (4)ICU内で死 亡 (30症例), (5)治療を差し控えてのICU退室 (22症 例）を除いた 570 症例を対象とし (Fig. 1)，後方視的診 療録調査を行った。

調查項目は, 年齢, 身長, 体重, ICU入室時の Acute Physiology and Chronic Health Evaluation (APACHE) II スコア2), 入院から ICU入室までの日 数, 主治療科 (脳神経外科, 心臟外科, 腹部外科, 血管 外科, その他の外科, 血液内科, 腎臟内科, その他の内 科), 入室経路 (手術室, 救急室, 病棟), 併存疾患 (癌 転移, 血液悪性腫瘍, 免疫抑制状態, 血液透析, 心不全, 呼吸不全, 肝不全)の有無, ICU内で行った治療 (人工 呼吸, 再插管, 腎代替療法, 気管切開, 非侵襲的陽圧換

\footnotetext{
*1自治医科大学附属さいたま医療センター麻醉科集中治療部

（テ330-8503 埼玉県さいたま市大宮区天沼町 1-847）

*2 東京慈恵会医科大学麻醉科集中治療部 ( 7 105-8471 東京都港区西新橋3-19-18) 


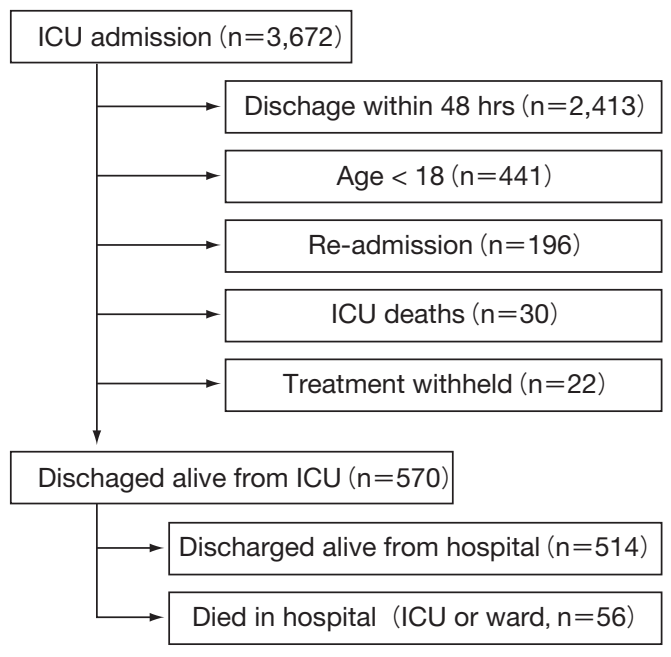

Fig. 1 Patient flow chart

気）の有無, 耐性菌の有無, 人工呼吸器を装着しての ICU 退室の有無, ICU在室日数, 入院日数, 夜間退室 の有無とした。夜間退室は20時から8時までの間の 退室と定義した。院内死亡群については, さらにICU への再入室の有無と死亡原因について, 医療記録を後 方視的に調查した。死亡原因は, 2 名の集中治療専従 医が院内死亡患者のすべての医療記録を検討し, (1)病 棟での突然の心停止, (2)感染症死 (重篤な感染症のた め全身状態が悪化して死亡), (3)悪性腫瘍死 (病棟で加 療中に悪性腫瘍が進行し死亡), (4)脳血管障害死 (病棟 で新たな脳血管障害を発症し死亡), (5)その他，に分類 した。

結果は症例数と群内における割合, あるいは中央値 と四分位範囲で示した。統計処理は, 年齢, 身長, 体重, APACHE II スコア，入院からICU入室までの日数, ICU 在室日数, 入院日数はMann-WhitneyのU 検定, 主治療科, 入室経路についてはカイ二乗検定, その他 の項目につてはFisherの直接法にて行った。また, ICU 退室後の死亡に対する危険因子について検討する ため, 上記患者背景の項目を用いた多変量ロジス ティック回帰分析を行い, オッズ比 (odds ratio, OR) を算出した。すべての項目につき, $P<0.05$ にて有意 とした。

この研究は, 東京慈恵会医科大学倫理委員会にて承 認を得ており, 後ろ向き研究で個人の匿名性は確保さ れていることから, 文書による同意の取得は不要と判 断された。

\section{結 果}

検討対象の 570 症例のうち, 院内死亡は 56 症例 （9.8\%）であった。ICU入室時の患者背景をTable 1に
示す。生存退院群に比べ, 院内死亡群において年齢お よびAPACHE II スコアが高く，入院から ICU入室ま での期間は長かった。主治療科による分類においては, 血液内科, その他の内科, 腹部外科の順に院内死亡が 多く, 診療科の分布に有意な差を認めた $(P<0.0001)$ 。 また, ICU入室経路については, 病棟から入室した患 者で死亡率が高かった (ICU退室後に $25 \%$ が死亡)。 入室時の併存疾患に関しては, 癌転移 $(P=0.0078)$, 血液悪性腫瘍 $(P=0.0007)$, 免疫抑制状態 $(P=0.0043)$ が院内死亡群で有意に多かった。

ICU内で行われた治療抢よび転帰をTable 2 に示 す。治療については, 人工呼吸療法以外のすべての項 目が院内死亡群で有意に多かった。耐性菌の検出 $(P=0.0056)$, 人工呼吸器を装着してのICU退室 $(P=0.0013), \mathrm{ICU}$ 在室日数 $(P=0.0023)$, 入院期間 $(P=0.0016)$ に関しても, すべて院内死亡群で有意に 多い結果となった。特に，再捚管された 22 症例のう ち 15 症例 $(P=0.0032)$, 人工呼吸器を装着して ICU を退室した 36 症例のうち 26 症例 $(P=0.0013)$ が院内 死亡しているという結果であった。夜間退室は5 症例 で，いずれも生存退院していた。

院内死亡についての多変量ロジスティック回帰分析 の結果を Table 3 に示す。院内死亡の独立した危険因 子は, 病棟からの入室 $(\mathrm{OR}=2.69)$, 癌転移の存在 $(\mathrm{OR}$ $=41.0)$, 血液悪性疾患の存在 $(\mathrm{OR}=9.71), \mathrm{ICU}$ 入室 時の APACHE II スコア (OR=1.11 per point), 再扱 管の施行 $(\mathrm{OR}=5.59)$, 人工呼吸器を装着しての ICU 退室 $(\mathrm{OR}=3.19)$ であった。

院内死亡群の死亡原因と ICU 再入室の有無を Table 4 に示す。最も多い死亡原因は感染症の 27 症例 $(48.2 \%)$ で感染症で死亡した症例のうち, 12 症例は ICUに再入室していた。ICU 退室後, 病棟で突然の心 停止を発症した症例は7症例 (12.5\%) 存在した。4症 例は蘇生されICUへ再入室したが, 3 症例は蘇生でき ずそのまま病棟にて死亡した。脳血管障害死は 3 症例 で，いずれも ICUへ再入室していた。悪性疾患死の 11 症例は全例病棟で死亡していた。ICUに再入室した 24 症例のうち 16 症例はICU内で死亡し，8症例は再度 ICUを退室後, 病棟にて死亡していた。

\section{考 察}

今回我々は, 当院 ICU 退室後の院内死亡について検 討した。Rowanらは, ICU患者の院内死亡率は平均 $27.7 \%$ で, $17.9 \%$ がICU内で, $9.8 \%$ はICU退室後に病 棟にて死亡していると報告している1)。今回の我々の 検討では，予定手術後の患者など 48 時間以内にICU 
Table 1 Patient characteristics at ICU admission

\begin{tabular}{|c|c|c|c|}
\hline & $\begin{array}{l}\text { Survivors } \\
(\mathrm{n}=514)\end{array}$ & $\begin{array}{l}\text { Non-survivors after } \\
\text { ICU discharge }(n=56)\end{array}$ & $P$ value \\
\hline Age (years) & $65(54 \sim 74)$ & $70(61 \sim 77)$ & 0.031 \\
\hline Male (\%) & $336(65.4 \%)$ & $43(76.8 \%)$ & 0.10 \\
\hline Height $(\mathrm{cm})$ & $163(155 \sim 169)$ & $164(159 \sim 170)$ & 0.53 \\
\hline Weight $(\mathrm{kg})$ & $59(50 \sim 68)$ & $54(43 \sim 65)$ & 0.033 \\
\hline APACHE II score & $16(11 \sim 21)$ & $22(18 \sim 27)$ & $<0.0001$ \\
\hline $\begin{array}{l}\text { Interval between hospital admission } \\
\text { and ICU admission (days) }\end{array}$ & $2(0 \sim 7)$ & $5.5(0 \sim 26)$ & 0.012 \\
\hline Parent unit & & & $<0.0001$ \\
\hline Neurosurgery & $132(25.7 \%)$ & $6(10.7 \%)$ & \\
\hline Cardiac surgery & $135(26.3 \%)$ & $3(5.4 \%)$ & \\
\hline Abdominal surgery & $95(18.5 \%)$ & $17(30.4 \%)$ & \\
\hline Vascular surgery & $53(10.3 \%)$ & $8(14.3 \%)$ & \\
\hline Other surgical units & $49(9.5 \%)$ & $6(10.7 \%)$ & \\
\hline Hematology & $5(1.0 \%)$ & $4(7.1 \%)$ & \\
\hline Nephrology & $15(2.9 \%)$ & $2(3.6 \%)$ & \\
\hline Other medical units & $30(5.8 \%)$ & $10(17.9 \%)$ & \\
\hline Admission route & & & $<0.0001$ \\
\hline Operation room & $347(67.5 \%)$ & $21(37.5 \%)$ & \\
\hline Emergency room & $102(19.8 \%)$ & $13(23.2 \%)$ & \\
\hline Ward & $65(12.6 \%)$ & $22(39.3 \%)$ & \\
\hline \multicolumn{4}{|l|}{ Comorbidities } \\
\hline Metastatic cancer & $2(0.4 \%)$ & $3(5.4 \%)$ & 0.0078 \\
\hline Hematologic malignancy & $4(0.8 \%)$ & $5(8.9 \%)$ & 0.0007 \\
\hline Immunocompromised & $16(3.1 \%)$ & $7(12.5 \%)$ & 0.0043 \\
\hline Chronic dialysis & $48(9.3 \%)$ & $5(8.9 \%)$ & $>0.99$ \\
\hline Heart failure & $2(0.4 \%)$ & $0(0 \%)$ & $>0.99$ \\
\hline Respiratory failure & $5(1.0 \%)$ & $2(3.6 \%)$ & 0.14 \\
\hline Hepatic failure & $3(0.6 \%)$ & $1(1.8 \%)$ & 0.34 \\
\hline
\end{tabular}

Results are shown as number (percentage in the group) or median(inter-quartile range).

APACHE II, Acute Physiology and Chronic Health Evaluation II.

Table 2 Treatment in ICU and outcomes

\begin{tabular}{lccc}
\hline \hline & $\begin{array}{c}\text { Survivors } \\
(\mathrm{n}=514)\end{array}$ & $\begin{array}{c}\text { Non-survivors after } \\
\text { ICU discharge }(\mathrm{n}=56)\end{array}$ & $P$ value \\
\hline Treatment in ICU & & & \\
$\quad$ Mechanical ventilation & $410(79.8 \%)$ & $42(75.0 \%)$ & 0.389 \\
$\quad$ Re-intubation & $7(1.4 \%)$ & $15(26.8 \%)$ & 0.0032 \\
$\quad$ Renal replacement therapy & $75(14.6 \%)$ & $17(30.4 \%)$ & 0.0063 \\
$\quad$ Tracheostomy & $83(16.1 \%)$ & $21(37.5 \%)$ & 0.0004 \\
$\quad$ Noninvasive positive pressure ventilation & $54(10.5 \%)$ & $12(21.4 \%)$ & 0.025 \\
Drug-resistant bacteria & $39(7.6 \%)$ & $11(19.6 \%)$ & 0.0056 \\
ICU discharge with mechanical ventilation & $10(5.1 \%)$ & $26(46.4 \%)$ & 0.0013 \\
Night time discharge & $5(1.0 \%)$ & $0(0 \%)$ & $>0.99$ \\
ICU stay (days) & $4(2.8 \sim 6.5)$ & $5.8(3.6 \sim 9.8)$ & 0.0023 \\
Hospital stay (days) & $42(27 \sim 68)$ & $60(34 \sim 133)$ & 0.0016 \\
\hline
\end{tabular}

Results are shown as number (percentage in the group) or median (inter-quartile range). 
Table 3 Variables associated with death after ICU discharge (multivariate analysis)

\begin{tabular}{lcc}
\hline \hline Variables & Odds ratio $(95 \% \mathrm{CI})$ & $P$ value \\
\hline Admission route & $1.00($ Ref $)$ & \\
$\quad$ Operation room & $1.81(0.81 \sim 4.04)$ & 0.30 \\
$\quad$ Emergency room & $2.69(1.22 \sim 5.96)$ & 0.0087 \\
$\quad$ Ward & $41.0(4.70 \sim 357)$ & 0.0009 \\
Metastatic cancer & $9.71(2.26 \sim 41.7)$ & 0.0028 \\
Hematologic malignancy & $1.11(1.06 \sim 1.16)$ & $<0.0001$ \\
APACHE II score (per point) & $5.59(1.87 \sim 16.6)$ & 0.0025 \\
Re-intubation & $3.19(1.31 \sim 7.80)$ & 0.0095 \\
ICU discharge with mechanical ventilation &
\end{tabular}

APACHE II, Acute Physiology and Chronic Health Evaluation II; CI, confidence interval; Ref, reference category.

Table 4 Causes of death after ICU discharge

\begin{tabular}{lccr}
\hline \hline & $\begin{array}{c}\text { All non-survivors } \\
(\mathrm{n}=56)\end{array}$ & $\begin{array}{c}\text { With ICU } \\
\text { re-admission } \\
(\mathrm{n}=24)\end{array}$ & $\begin{array}{c}\text { Without ICU } \\
\text { re-admission } \\
(\mathrm{n}=32)\end{array}$ \\
\hline Infection & $27(48.2 \%)$ & $12(50.0 \%)$ & $15(46.9 \%)$ \\
$\quad$ Pneumonia & $14(25.0 \%)$ & $6(25.0 \%)$ & $8(25.0 \%)$ \\
$\quad$ Other infection & $13(23.2 \%)$ & $6(25.0 \%)$ & $7(21.9 \%)$ \\
Malignancy & $11(19.6 \%)$ & $0(0.0 \%)$ & $11(34.4 \%)$ \\
Sudden cardiac arrest & $7(12.5 \%)$ & $4(16.7 \%)$ & $3(9.4 \%)$ \\
Cerebrovascular accident & $3(5.4 \%)$ & $3(12.5 \%)$ & $0(0.0 \%)$ \\
Others & $8(14.3 \%)$ & $5(20.8 \%)$ & $3(9.4 \%)$ \\
\hline
\end{tabular}

Others: uncontrollable multiple organ dysfunction (2 cases), exacerbation of interstitial pneumonia, respiratory failure, gastrointestinal bleeding with coagulopathy, asphyxia due to re-bleeding from tracheo-aortic-fistula, cardiac tamponade after replacement of the ascending aorta and pulmonary embolism.

Results are shown as number (percentage in the group).

を退室した患者を検討対象から除外しており患者背景 が同等ではないが, 48 時間以上ICUに在室した患者の うち約 1 割が退室後に病棟で死亡していた。

今回の多変量解析の結果, 病棟からのICU入室は, ICU 退室後院内死亡の独立した危険因子であった $(\mathrm{OR}=2.69)$ 。この因子は過去の文献でも指摘されて 打り 31,4$)$, 手術室や救急外来から ICUに入室する患者 と比較して, 合併症が多く予備能がそしいことが影響 していると考えられた。

人工呼吸器を装着してのICU 退室も有意な危険因 子であった $(\mathrm{OR}=3.19)$ 。人工呼吸管理はそれ自体が 綿密なモニタリングや看護を必要とするが, 一般病棟 でそのような管理を行うことが困難であることは容易 に想像できる。Chaboyerらは, ICU退室後の有害事 象発生の危険因子が, 呼吸数の異常, 頻脈, 高い看護 必要度であることを指摘している5)。今回は退室後の 有害事象の発生について検討していないが, 病棟にて
人工呼吸管理中の患者は複数の危険因子に該当し, 有 害事象発生の危険性が高いと考えられた。

再挿管の施行も有意な危険因子であった $(\mathrm{OR}=$ 5.59)。再挿管はICU患者において院内肺炎の増加, ICU 在室日数増加, 入院期間延長, 死亡率上昇の危険

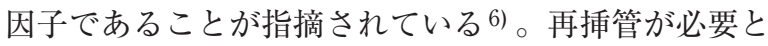
なった患者は, (1)再挿管が院内肺炎などの合併症を増 加させる，(2)抜管から再抻管の間に全身状態が悪化す る, (3)再拝管は全身状態が悪いことの強力な指標であ る, などの理由により, ICUから退室後も再抻管が必 要でなかった患者に比べ，より重症であると考えられ る。過去の文献で, 再挿管はICU 退室後院内死亡の危 険因子としては指摘されていないが7)，そもそもこの 因子についての検討が行われていなかった。しかし， 今回の我々の検討により, 再挿管が血液浄化や気管切 開よりも強い危険因子であることが示唆された。再挿 管された患者には, ICU退室後もより注意深い観察が 
必要であろう。

感染症でICUに再入室した症例のなかには, ICU退 室後 3 日以内に再入室している症例が 4 例あり, ICU 退室時点で十分に感染症が制御できていなかった可能 性が考えられる。重症化したにもかかわらずICUに 再入室しなかった症例のなかには, 適切な治療により 救命の可能性があったと考えられる症例も含まれてい た。一方, 病棟での予期せぬ心停止により 7 症例が死 亡していた。後方視的な検討であり, 心停止の理由は 評価できなかったが, ICU退室患者に対しては緊密な モニタリングが必要であると考えられた。

ICUからの退室症例のみを対象とした研究の少なさ に比べ3)〜5),8), ICUに入室した全症例を対象に死亡の 危険因子を検討した研究は非常に多い。重症度スコア についての検討がその典型例であるが2),9),10), 本研究 で示されたICU退室後院内死亡の危険因子 (Table 3) のほとんどはICU入室時の重症度スコアそのものか, 重症度スコアの構成要素であった。つまり, ICU入室 時の重症度が, ICUを生存退室後も患者の予後に強い 影響を与えるということを示している。この事実が, ICU退室後の死亡はある程度不可避であることを示し ているのか, それとも一施設の後ろ向き研究であるた め検討された項目が少なく, 修飾可能な因子が他にあ るのか, 推測は困難である。今後, ICU退室後院内死 亡についてのさらなる研究が行われ, 患者予後を改善 しうる知見が得られることを期待したい。

本研究にはいくつかの問題点が存在する。まず, 治 療の差し控えは重要なICU退室後院内死亡の危険因 子と報告されているが3), 今回の研究ではICU内で治 療を差し控える方針となった患者をすべて網羅できて いない可能性があったため, このことについての検討 は行えなかった。また, ICU退室後の院内死亡のみを 評価対象としたが, 実際には生存退院した症例のなか にも重度の後遺症を抱えた症例があったと考えられ た。死亡症例のみを対象とした研究は, ICUの転帰の 評価としては不十分であることが指摘されており ${ }^{8)}$, 今後はそのような点についても検討が必要であると考 えられる。また, 当施設には明文化されたICU退室基 準はなく, それに起因する早期退室があった可能性が 否定できない。今後は退室基準について検討していく 必要があると考えられた。

最後に, 本研究は単施設の後ろ向き観察研究であり,
日本におけるICU退室後の患者の転帰に関するさら なる研究が望まれる。

\section{結 語}

48 時間以上ICUに在室後に退室した患者のうち, 約 1割の患者が院内死亡していた。院内死亡の有意な危 険因子は, (1)病棟からのICU入室, (2)癌転移, (3)血液 悪性疾患, (4)再扦管の施行, 5人工呼吸器を装着して のICU退室であった。ICU退室後の院内死亡を減少さ せるために, 退室時の危険因子の評価と適切な再入室 を促すシステムについてのさらなる評価が必要であ る。

本論文のすべての著者には規定された利益相反 (COI) は ない。

\section{文 献}

1) Rowan KM, Kerr JH, Major E, et al. Intensive Care Society's APACHE II study in Britain and Ireland--I: Variations in case mix of adult admissions to general intensive care units and impact on outcome. BMJ 1993; 307:972-7.

2) Knaus WA, Draper EA, Wagner DP, et al. APACHE II: a severity of disease classification system. Crit Care Med 1985;13:818-29.

3) Azoulay E, Adrie C, De Lassence A, et al. Determinants of postintensive care unit mortality: a prospective multicenter study. Crit Care Med 2003;31:428-32.

4) Iapichino G, Morabito A, Mistraletti G, et al. Determinants of post-intensive care mortality in high-level treated critically ill patients. Intensive Care Med 2003;29:1751-6.

5) Chaboyer W, Thalib L, Foster M, et al. Predictors of adverse events in patients after discharge from the intensive care unit. Am J Crit Care 2008;17:255-63.

6) Epstein SK, Ciubotaru RL, Wong JB. Effect of failed extubation on the outcome of mechanical ventilation. Chest 1997;112:186-92.

7) Mayr VD, Dünser MW, Greil V, et al. Causes of death and determinants of outcome in critically ill patients. Crit Care 2006;10:R154.

8) Eddleston JM, White P, Guthrie E. Survival, morbidity, and quality of life after discharge from intensive care. Crit Care Med 2000;28:2293-9.

9) Knaus WA, Wagner DP, Draper EA, et al. The APACHE III prognostic system. Risk prediction of hospital mortality for critically ill hospitalized adults. Chest 1991;100:1619-36.

10) Le Gall JR, Lemeshow S, Saulnier F. A new Simplified Acute Physiology Score (SAPS-II) based on a European/ North American multicenter study. JAMA 1993;270: 2957-63. 


\title{
Abstract
}

\section{Risk factors for unexpected death after ICU discharge}

\author{
Kazuto Yamashita*1, Yusuke Mazda*2, Shigehiko Uchino*2, Arata Endo*2, Kenichi Iwai*2, \\ Keita Saito*2, Yoichi Kase*2, Masanori Takinami*2 \\ ${ }^{* 1}$ Department of Anesthesiology and Critical Care Medicine, Jichi Medical University Saitama Medical Center \\ ${ }^{* 2}$ Intensive Care Unit, Department of Anesthesiology, Jikei University School of Medicine \\ *11-847 Amanuma-cho, Omiya-ku, Saitama, Saitama 330-8503, Japan \\ *2 3-19-18 Nishi-Shinbashi, Minato-ku, Tokyo 105-8471, Japan
}

Background: Some patients who are admitted to the ICU die after their discharge from the ICU. The purpose of this study was to investigate the occurrence and cause of death during hospitalization in patients who were discharged from the ICU. Methods: We retrospectively collected data for 570 patients who were admitted to our ICU between 2006 and 2008 and who did not meet the following exclusion criteria: discharge from the ICU within 48 hours; age < 18 years; re-admission to ICU; death during ICU stay; and treatment withhold. Results: 56 patients died during their hospitalization, and a multivariate analysis revealed the presence of 6 independent predictors of death after ICU discharge: admission from the ward [OR (odds ratio) $=2.69$ ], metastatic cancer $(\mathrm{OR}=41.0)$, hematologic malignancy $(\mathrm{OR}=9.71)$, Acute Physiology and Chronic Health Evaluation (APACHE) II score (OR $=1.11$ per point), re-intubation $(\mathrm{OR}=5.59)$ and ICU discharge with mechanical ventilation $(\mathrm{OR}=3.19)$. The major causes of death after ICU discharge were infection, progression of malignancy, and sudden cardiac arrest. Conclusion: About 10\% of patients who were discharged from the ICU died during their hospitalization. Further evaluation of risk factors at ICU discharge is needed.

Key words: (1) mortality, (2) post ICU discharge 